\title{
Response of Different Sources and Levels of Sulphur on Quality and Grading of Onion (Allium cepa L.)
}

\author{
Bhoite Vivek* and M.R. Backiyavathy \\ Department of Soil Science and Agricultural Chemistry, Tamil Nadu Agriculture University, \\ Coimbatore, India \\ *Corresponding author
}

\section{A B S T R A C T}

\begin{abstract}
Onion is one of the important and commercial vegetable crops of India. Onion is sulphur loving crop and its requirement is high for improved yield and quality. Sulphur has been recognized as an important nutrient for higher yield, quality and nutrient uptake of onion bulbs. Keeping these in view, a field experiment was conducted at ICAR- National Institute on Abiotic Stress Management (ICAR - NIASM), Baramati, during Rabi, 2017-18 to study the effect of sources and levels of sulphur on bulb quality and grading in onion (cv. Bhima Kiran). The treatments consisted of three sources of sulphur (Elemental sulphur- Bentonite clay, Potassium schoenite and ammonium sulphate) and four levels of sulphur viz., 0 , 30,45 and $60 \mathrm{~kg} \mathrm{~S}^{-1}$ by adopting RBD with three replications. The results on phenol, flavonoide, ascorbic acid, pyruvic acid, total soluble solids (TSS \%) and grading of onion bulb viz., of A, B, C \% revealed significance variations among the levels of sulphur in onion. Maximum phenol content was registered@ $45 \mathrm{~kg} \mathrm{~S} \mathrm{ha}^{-1}$ as elemental sulphur + thiobacillus by soil application. There was equal behaviour of three rates of application of sulphur viz., 30,45 and $60 \mathrm{~kg} \mathrm{~S}^{-1}$ through three sources in relation to flavonoid content. Sulphur fertilization significantly increased the ascorbic acid content of onion when applied through potassium schoenite, elemental sulphur and ammonium sulphate. Maximum ascorbic acid content of $4.69 \mathrm{mg} \mathrm{g}^{-1}$ was noted @ $60 \mathrm{~kg} \mathrm{~S} \mathrm{ha}^{-1}$ through potassium schoenite by soil application. The production of pyruvic acid content in onion was enhanced significantly owing to sulphur fertilization. Maximum total soluble solids to the tune of $12.93 \%$ were noticed @ $45 \mathrm{~kg} \mathrm{~S}^{-1}$ as elemental sulphur + thiobacillus by soil application $\left(45\right.$ and $\left.60 \mathrm{~kg} \mathrm{~S}^{-1}\right)$. The grading of onion is judged by grading of the bulbs significantly higher percentage of ' $\mathrm{A}$ ' grade onion bulbs were obtained by $45 \mathrm{~kg} \mathrm{~S} \mathrm{ha}{ }^{-1}$ through potassium schoenite through nutripellet pack noted (95.2\%).
\end{abstract}

\section{Introduction}

Onion (Allium cepa L.) is one of the most important commercial vegetable crops and is widely grown in almost all over the world. In India, onion crop is under cultivation for the last 5000 years mainly in tropical condition. India ranks first in area and second in production after China, but the productivity are much lower as compared to the leading producers namely China, USA and The Netherlands etc. India is second largest producer of onion next to China in the world, cultivating onion over an area of 1320 thousand hectare with total production of 20931 thousand metric tonnes accounting for 26.8 percent of world area and 19.9 percent of onion production., with an average yield of 14.2 tha $^{-1}$ (Anonymous, 2017). The yield is very low as compared to the world average yield of $19.1 \mathrm{t} \mathrm{ha}{ }^{-1}$. Intensive cropping, imbalanced fertilization and minimal usages of micronutrients and limited application of organic manures have resulted in the depletion 
of soil fertility in India. Maharashtra is leading state in onion production in India. Total area was 441.9 thousand ha, production was 5362 thousand MT and productivity was $12.13 \mathrm{t} \mathrm{ha}^{-1}$. Onion has its own distinctive flavour and is widely grown in almost all over the world. It is used in soups, different dishes, sandwiches and is also cooked alone as a vegetable. Onion is a temperate crop but can be grown under a wide range of climatic conditions such as temperate, tropical and subtropical climate. The best performance can be obtained in a mild whether without the extremes of cold and heat and excessive rainfall. In India, short day onion is grown in the plains and requires 1012 hours day length. Its pungency is due to the presence of allyl propyl disulphide, a volatile oil (Malik, 1994). Onion can be grown in all types of soils such as sandy loam, clay loam, silt loam and heavy soils. At present, pungency in onion is decreased and similarly taste and quality of bulb is also hampered due to the application of imbalanced chemical fertilizers. The pungency in onion is due to the presence of sulphur bearing compound in the volatile oil known as allyl-propyl disulphide $\left(\mathrm{C}_{6} \mathrm{H}_{12} \mathrm{~S}_{2}\right)$. The colour of the outer skin of onion bulb is due to the presence of quercetin. Catechol is a phenolic factor present in onion which has anti-fungal properties. Onion is known to possess several medicinal and therapeutic properties, its effectiveness range against common cold to diabetes, heart diseases, ostreoporosis and diseases, Sulphur is associated with the production of crop of superior nutritional and market quality. Sulphur is also required for the synthesis of three important essential amino acids such as cystine $(27 \% \mathrm{~S})$, cysteine $(26 \% \mathrm{~S})$ and methionine $(21 \% \mathrm{~S})$ besides increasing allyl propyl disulphide alkaloid $(43 \% \mathrm{~S})$ and the capsaicin, the principle alkaloids responsible for pungency in onion (Randle and Bassard, 1993).Onion is an important sulphur -loving crop. Sulphur improves the yield and quality of onion. Sulphur is recognized as the fourth major plant nutrient after nitrogen, phosphorus and potassium in crops. Hence the present study was carried out to evaluate the effect of different sources and levels of sulphur on quality and grading of onion.

\section{Materials and Methods}

A field experiment was conducted at National Institute on Abiotic Stress Management (ICAR-NIASM), Malegaon Kurd, Baramati, Pune, Maharashtra during rabi season 2017-18 and 2018-19 with onion cv. Bhima Kiran. The soil of the experimental field was clay loam in texture, $\mathrm{pH}(1: 2.5) 8.2$, electrical conductivity $0.26 \mathrm{dSm}^{-1}$, organic carbon $4.40 \mathrm{~g} \mathrm{~kg}^{-1}$, available $\mathrm{N} 93.99 \mathrm{~kg} \mathrm{ha}^{-1}, \mathrm{P} 10.75 \mathrm{~kg} \mathrm{ha}^{-1}, \mathrm{~K}$ $277 \mathrm{~kg} \mathrm{ha}^{-1}$ and S $6.30 \mathrm{ppm}$. The irrigation water contained $1.6 \mathrm{ppm}$ of sulphur. A field experiment was conducted in randomized block design. Four levels of sulphur $(0,30,45$ and $60 \mathrm{~S} \mathrm{~kg} \mathrm{ha}{ }^{-1}$ ) were applied through elemental sulphur (80 \% S as Bentonite clay), potassium schoenite $(22 \% \mathrm{~S})$ and ammonium sulphate $(24 \% \mathrm{~S})$ The experiment comprised 14 treatments: $\mathrm{T}_{1}-$ Absolute Control; $\mathrm{T}_{2}-\mathrm{RDF}$ $+\mathrm{S} @ 30 \mathrm{~kg} \mathrm{ha}^{-1}$ soil application; $\mathrm{T}_{3^{-}}$ $\mathrm{RDF}+\mathrm{S} @ \quad 45 \mathrm{~kg} \quad \mathrm{ha}^{-1}$ aselementalS+ Thiobacillus -Soil application; $\mathrm{T}_{4}$ - RDF + S@ $60 \mathrm{~kg} \mathrm{ha}^{-1}$ as elemental S+ Thiobacillus - Soil application; $\mathrm{T}_{5-} \mathrm{RDF}+\mathrm{S} @ 45 \mathrm{~kg} \mathrm{ha}^{-1}$ as elemental $\mathrm{S}+$ Thiobacillus by Nutripellet Pack; $\mathrm{T}_{6}-\mathrm{RDF}+\mathrm{S} @ 60 \mathrm{kgha}^{-1}$ as elemental S+ Thiobacillus by Nutripellet Pack; $\mathrm{T}_{7}-\mathrm{RDF}$ $+\mathrm{S} @ 45 \mathrm{~kg} \mathrm{ha}^{-1}$ as Potassium Schoenite by Soil application; $\mathrm{T}_{8}-\mathrm{RDF}+\mathrm{S} @ 60 \mathrm{~kg} \mathrm{ha}^{-1}$ as Potassium Schoenite-Soil application; $\mathrm{T}_{9}$ $\mathrm{RDF}+\mathrm{S} @ 45 \mathrm{~kg} \mathrm{ha}^{-1}$ as Potassium Schoenite Nutripellet Pack; T 10 - RDF +S@ $60 \mathrm{~kg} \mathrm{ha}^{-1}$ as Potassium Schoenite - Nutripellet Pack ; $\mathrm{T}_{11^{-}}$ $\mathrm{RDF}+\mathrm{S} @ 45 \mathrm{~kg} \mathrm{ha}^{-1}$ as Ammonium Sulphate -Soil application; $\mathrm{T}_{12}-\mathrm{RDF}+\mathrm{S} @ 60 \mathrm{~kg} \mathrm{ha}^{-1}$ as Ammonium Sulphate -Soil application; $\mathrm{T}_{13}$ $\mathrm{RDF}+\mathrm{S} @ 45 \mathrm{~kg} \mathrm{ha}^{-1}$ as Ammonium Sulphate - Nutripellet Pack; T14 - RDF +S@60 kg ha ${ }^{-1}$ as Ammonium Sulphate - Nutripellet Pack. 
The experiment was laid out in randomized block design with three replications. Individual plot size was $3 \times 4 \mathrm{~m}$ and plant spacing was $15 \times 10 \mathrm{~cm}$. Recommended dose of $\mathrm{N}: \mathrm{P}_{2} \mathrm{O}_{5}: \mathrm{K}_{2} \mathrm{O}\left(110: 40: 60 \mathrm{~kg} \mathrm{ha}^{-1}\right)$ was applied to all the plots except control. The sources of nitrogen, phosphorus and potassium were Urea, Di ammonium phosphate and Murate of potash respectively.50 percent nitrogen and full dose of phosphorus, potassium and sulphur were applied at the time of transplanting. Remaining 50 per nitrogen was applied two equal splits at 30 and 45 days after transplanting. Onion cultivar Bhima Kiran was selected for the study. Transplanting of onion was done on $20^{\text {th }}$ January, 2018. Standard package of practices were followed to grow onion crop. The crop was harvested at 120 days after transplanting on $20^{\text {th }}$ May, 2018. Bulbs were covered by its top and left in the field for curing for 3-4 days. After neck cutting, bulb yield was recorded.

Representative bulb samples were collected for the biochemical and nutritional analysis. Chopped bulb samples were dried in oven at $60^{\circ} \mathrm{C}$ till the constant weight was attained. While the plant samples were digested using nitric acid and perchloric acid mixture, the plant digests and soil extractant were used for estimating the sulphur content using Turbidimetric method (Chesnin and Yien, 1950). The total soluble solid (TSS) of onion bulbs were estimated using hand refractometer and the percent TSS was noted down. Pyruvic acid content was estimated using dinitro phenyl hydrazine (DNPH) reagent method. Two opposite quarters of onion bulbs were selected and made into pieces after removing the neck, basal plate and skin. The onion tissues were crushed in a stainless steel mixer grinder without adding water. Bulb tissues were blended with equal volumes of water for 10 minutes. The homogenate was filtered through Whatman No. 4 filter paper and the filtrate was used for pyruvic acid analysis
(Schwimmer and Weston, 1961). The quality parameters viz., phenol, flavonoids, ascorbic acid, pyruvic acid and total soluble solids were recorded at the time of harvest. After harvesting, bulbs were graded on the basis of size. The onion having equatorial diameter less than $35.00 \mathrm{~mm}$ recorded as "unmarketable grade". 35.00 to $45.00 \mathrm{~mm}$ as "C grade, 45.00 to $55.00 \mathrm{~mm}$ as "B grade" and 55.00 to 65.00 $\mathrm{mm}$ as "A grade". The data recorded on various parameters were subjected to statistical analysis as per the procedure suggested by Sukhatme and Amble (1995)

\section{Results and Discussion}

The data on quality parameters such as phenols, flavonoide, ascorbic acid, pyruvic acid, total soluble solids and grading of onion bulbs as influenced by different sources and levels of sulphur in onion variety Bhima Kiran are presented in table 1 .

\section{Phenols}

The phenol content of onion was increased significantly due to sulphur application through different sources over control treatment. Phenol content was maximum due to application of $45 \mathrm{~kg} \mathrm{~S} \mathrm{ha}{ }^{-1}$ through elemental sulphur + thiobacillus $\left(4.95 \mathrm{mg} \mathrm{g}^{-1}\right)$ which was significantly superior over all other treatments receiving sulphur through different sources at different rate of application.

\section{Flavonoids}

A application of sulphur at different rates and through different sources increased the flavonoide content of onion. Maximum flavonoid content of $327 \mu$ mole $\mathrm{g}^{-1}$ was obtained at $60 \mathrm{~kg} \mathrm{~S} \mathrm{ha}{ }^{-1}$ through elemental sulphur and thiobacillus, which was statistically at par with $45 \mathrm{~kg} \mathrm{~S} \mathrm{ha}^{-1}$ for both elemental sulphur + Thiobacillus and potassium schoenite. 
Table.1 Response of different sources and levels of sulphur on quality and grading of bellary onion

\begin{tabular}{|c|c|c|c|c|c|c|c|c|}
\hline Treatments & $\begin{array}{l}\text { Phenols } \\
\text { mg/g }\end{array}$ & $\begin{array}{l}\text { Flavonoide } \\
\mu \text { mole/g }\end{array}$ & $\begin{array}{l}\text { Ascorbic } \\
\text { acid } \\
\mathrm{mg} / \mathrm{g}\end{array}$ & $\begin{array}{l}\text { Pyruvic } \\
\text { acid } \\
\mu \text { mole/g }\end{array}$ & TSS \% & $\begin{array}{l}\text { A grade } \\
\text { bulb } \\
(\%)\end{array}$ & $\begin{array}{c}\text { B grade } \\
\text { bulb } \\
(\%)\end{array}$ & $\begin{array}{l}\text { C grade } \\
\text { bulb } \\
(\%)\end{array}$ \\
\hline $\mathbf{T}_{1}$ Absolute Control & 1.34 & 161 & 2.44 & 0.64 & 9.70 & 70.57 & 4.62 & 0.93 \\
\hline $\mathrm{T}_{2} \mathrm{RDF}+\mathrm{S} @ 30 \mathrm{~kg} \mathrm{ha}^{-1}$ soil application & 2.73 & 203 & 3.39 & 1.31 & 11.76 & 83.89 & 3.35 & 0.35 \\
\hline $\begin{array}{l}\mathrm{T}_{3} \mathrm{RDF}+\mathrm{S} @ 45 \mathrm{~kg} \mathrm{ha}^{-1} \text { as elemental } \mathrm{S}+ \\
\text { Thiobacillus -Soil application }\end{array}$ & 4.95 & 296 & 4.48 & 1.74 & 12.93 & 83.61 & 2.64 & 0.17 \\
\hline $\begin{array}{l}\mathrm{T}_{4} \mathrm{RDF}+\mathrm{S} @ 60 \mathrm{~kg} \mathrm{ha}^{-1} \text { as elemental } \mathrm{S}+ \\
\text { Thiobacillus }- \text { Soil application }\end{array}$ & 3.36 & 327 & 4.02 & 2.64 & 11.93 & 84.22 & 3.48 & 0.23 \\
\hline $\begin{array}{l}\mathrm{T}_{5} \mathrm{RDF}+\mathrm{S} @ 45 \mathrm{~kg} \mathrm{ha}^{-1} \text { as elemental } \mathrm{S}+ \\
\text { Thiobacillus -Nutripellet Pack }\end{array}$ & 3.56 & 195 & 4.30 & 1.42 & 12.06 & 90.24 & 1.72 & 0.80 \\
\hline $\begin{array}{l}\mathrm{T}_{6} \mathrm{RDF}+\mathrm{S} @ 60 \mathrm{~kg} \mathrm{ha}^{-1} \text { as elemental } \mathrm{S}+ \\
\text { Thiobacillus }- \text { Nutripellet Pack }\end{array}$ & 3.6 & 204 & 3.88 & 1.31 & 11.96 & 84.45 & 2.34 & 0.52 \\
\hline $\begin{array}{l}\mathrm{T}_{7} \mathrm{RDF}+\mathrm{S} @ 45 \mathrm{~kg} \mathrm{ha}^{-1} \text { as Potassium Schoenite- } \\
\text { Soil application }\end{array}$ & 2.45 & 230 & 4.15 & 1.48 & 11.46 & 84.79 & 1.49 & 0.13 \\
\hline $\begin{array}{l}\mathrm{T}_{8} \mathrm{RDF}+\mathrm{S} @ 60 \mathrm{~kg} \mathrm{ha}^{-1} \text { as Potassium Schoenite- } \\
\text { Soil application }\end{array}$ & 2.76 & 219 & 4.69 & 1.58 & 12.3 & 84.19 & 2.92 & 0.78 \\
\hline $\begin{array}{l}\text { T9 RDF +S @ } 45 \mathrm{~kg} \mathrm{ha}^{-1} \text { as Potassium Schoenite - } \\
\text { Nutripellet Pack }\end{array}$ & 3.41 & 265 & 4.20 & 1.25 & 11.46 & 95.20 & 0.36 & 0.80 \\
\hline $\begin{array}{l}\mathrm{T}_{10} \mathrm{RDF}+\mathrm{S} @ 60 \mathrm{~kg} \mathrm{ha}^{-1} \text { as Potassium Schoenite - } \\
\text { Nutripellet Pack }\end{array}$ & 2.90 & 217 & 3.64 & 1.79 & 11.73 & 84.87 & 3.02 & 0.14 \\
\hline $\begin{array}{l}\mathrm{T}_{11} \mathrm{RDF}+\mathrm{S} @ 45 \mathrm{~kg} \mathrm{ha}^{-1} \text { as Ammonium Sulphate - } \\
\text { Soil application }\end{array}$ & 2.53 & 195 & 3.22 & 1.46 & 12.26 & 85.00 & 2.30 & 0.20 \\
\hline $\begin{array}{l}\mathrm{T}_{12} \mathrm{RDF}+\mathrm{S} @ 60 \mathrm{~kg} \mathrm{ha}^{-1} \text { as Ammonium Sulphate - } \\
\text { Soil application }\end{array}$ & 2.25 & 204 & 3.95 & 1.4 & 11.13 & 83.37 & 2.05 & 0.51 \\
\hline $\begin{array}{l}\mathrm{T}_{13} \mathrm{RDF}+\mathrm{S} @ 45 \mathrm{~kg} \mathrm{ha}^{-1} \text { as Ammonium Sulphate - } \\
\text { Nutripellet Pack }\end{array}$ & 2.53 & 203 & 3.84 & 1.24 & 10.7 & 82.37 & 2.86 & 0.60 \\
\hline $\begin{array}{l}T_{14} \text { RDF +S @ } 60 \mathrm{~kg} \mathrm{ha}^{-1} \text { as Ammonium Sulphate - } \\
\text { Nutripellet Pack }\end{array}$ & 2.26 & 241 & 4.17 & 1.02 & 10.83 & 84.64 & 2.84 & 0.26 \\
\hline SED & 0.084 & 19.24 & 0.08 & 0.11 & 0.05 & 1.92 & 1.77 & 0.91 \\
\hline $\mathrm{CD}(\mathrm{p}=\mathbf{0 . 0 5})$ & 0.199 & 46.28 & 0.19 & 0.28 & 0.13 & 3.95 & 2.52 & 1.01 \\
\hline
\end{tabular}

RDF: STCR based of NPK fertilizers 
There was equal behavior of three rates of application of sulphur viz.30, 45 and $60 \mathrm{~kg} \mathrm{~S}$ ha ${ }^{1}$ through three sources in relation to flavonoid content.

\section{Ascorbic acid}

Sulphur fertilization significantly increased the ascorbic acid content of onion when applied through three sources of sulphur. Maximum ascorbic acid content of $4.69 \mathrm{mg} \mathrm{g}^{-1}$ was noted $@ 60 \mathrm{~kg} \mathrm{~S} \mathrm{ha}^{-1}$ through potassium schoenite by soil application, which was significantly higher over $0,30,45 \mathrm{~kg} \mathrm{~S} \mathrm{ha}^{-1}$ and other sources of sulphur. Navaldey and Ram (2014) reported that higher ascorbic acid (11.86 mg $\left.100 \mathrm{~g}^{-1}\right)$ in bulb was recorded at $40 \mathrm{~kg} \mathrm{~S}^{-1}{ }^{-1}$ There was equal response to onion crop to elemental sulphur and potassium schoenite applied @45 and $60 \mathrm{~kg} \mathrm{~S} \mathrm{ha}{ }^{-1}$ by either soil application or nutripellet pack. A significant increase in ascorbic acid content of bulbs with 40 and 60 $\mathrm{kg} \mathrm{S} \mathrm{ha}{ }^{-1}$ application was reported by Bharti et al., (2016).

\section{Pyruvic acid}

The data pertaining to pyruvic acid content of onion bulb indicating degree of pungency in onion are presented in table, which revealed that the production of pyruvic acid content in onion was enhanced significantly owing to sulphur fertilization. Application of RDF (NPK) $+30 \mathrm{~kg}$ $\mathrm{S} \mathrm{ha}^{-1}$ significantly increased the pyruvic acid content $\left(0.67 \mu\right.$ moles $\left.\mathrm{g}^{-1}\right)$ which was statistically at par with 45 and $60 \mathrm{~kg} \mathrm{~S} \mathrm{ha}^{-1}$ through elemental sulphur, potassium schoenite and ammonium sulphate by soil application. The previous studies indicated that the pungency level significantly increased with increasing the sulphur level in low sulphur soils (Qureshi and Lawande, 2006). Low pyruvic acid content of $3.20 \mu$ moles $\mathrm{g}^{-1}$ fresh weight was registered in control treatment. Pyruvic acid content was increased with increasing sulphur level up to $50 \mathrm{~kg} \mathrm{~S} \mathrm{ha}^{-1}$ (Thangasamy et. al. 2013). Zeinani et al., (2010) reported that the sulphur had positive effect on the pyruvic acid of the onion bulbs. Increasing the level of sulphur up to $150 \mathrm{~kg} \mathrm{ha}^{-1}$ resulted in increase of pyruvic acid of the bulbs. The present study showed that rate of increase in pyruvic acid content declined with increasing sulphur level.

\section{Total Soluble Solids}

In the present study, the total soluble solid content of onion bulb was not significantly influenced by sulphur application. Maximum total soluble solid content to the tune of 12.93 percent was noticed @ $45 \mathrm{~kg} \mathrm{~S} \mathrm{ha}{ }^{-1}$ as elemental sulphur + Thiobacillus by soil application, which were slightly higher than 45 and $60 \mathrm{~kg} \mathrm{~S}$ $\mathrm{ha}^{-1}$ and other sources of sulphur. Channagoudra et al., (2009) revealed that significantly higher pyruvic acid $\left(3.10 \mu\right.$ mole $\mathrm{g}^{-1}$ and TSS (12.26 per cent), content in onion bulbs were observed in $60 \mathrm{~kg} \mathrm{~S}^{-1}$ over $20 \mathrm{~kg} \mathrm{~S}^{-1}$ and no sulphur application but was at par with $40 \mathrm{~kg} \mathrm{~S} \mathrm{ha}^{-1}$. Application of elemental sulphur @ 45 and 60 $\mathrm{kg} \mathrm{S} \mathrm{ha}^{-1}$ with Thiobacillus significantly increased the TSS content of onion over $30 \mathrm{~kg} \mathrm{~S}$ $\mathrm{ha}^{-1}$ through same sources. Sulphur application @ $30 \mathrm{~kg} \mathrm{~S} \mathrm{ha}^{-1}$ though elemental sulphur is sufficient to meet the sulphur requirement of onion crop as compared to 45 and $60 \mathrm{~kg} \mathrm{~S}^{-1}$. Tripathy et al., (2013) found that keeping quality and TSS of onion bulbs were not significantly influenced by different sources of sulphur. Significantly highest TSS of 11.90 percent was recorded with the application of 30 $\mathrm{kg} \mathrm{S} \mathrm{ha}^{-1}$ than control $(10.32 \%)$.

\section{Grading of bulbs}

The quality of the onion can be judged by grading of the bulbs. Significantly higher percentage of ' $A$ ' grade onion bulbs were produced only in application of $45 \mathrm{~kg} \mathrm{~S} \mathrm{ha}^{-1}$ through potassium schoenite by nutripellet pack $(95.2 \%)$ and $45 \mathrm{~kg} \mathrm{~S} \mathrm{ha}^{-1}$ through elemental sulphur with thiobacillus through nutripellet pack $(90.2 \%)$. Thus potassium schoenite is the best source to increase the number of ' $A$ ' grade bulb. The study showed equal behaviour of different sources of sulphur fertilizer applied at 45 and $60 \mathrm{~kg} \mathrm{~S} \mathrm{ha}{ }^{-1}$ with soil application or nutripellet pack method in respect of production 
of ' $A$ ' grade bulb is concerned. The lowest percentages of ' $A$ ' grade bulb to the extent of 70.57 percent are recorded in control, showing the importance of sulphur. Maximum number of ' $\mathrm{B}$ ' grade onion was obtained at $45 \mathrm{~kg} \mathrm{~S} \mathrm{ha}^{-1}$ as potassium schoenite by nutripellet pack method. The differences in percentage of ' $\mathrm{C}$ ' grade onion produced in various levels and sources were nonsignificant. Although maximum production of ' $\mathrm{C}$ ' grade onions to the tune of 0.93 percent was recorded in control.

Application of $45 \mathrm{~kg} \mathrm{~S} \mathrm{ha}{ }^{-1}$ is found to be advantageous for achieving good quality and ' $A$ ' grade onion bulb in both the forms of sulphur such as elemental sulphur and potassium schoenite. Application of potassium schoenite is recommended in onion crop for better quality. The phenol content of onion is increased significantly due to sulphur application. Onion crop give equal response to elemental sulphur and potassium schoenite applied at 45 and $60 \mathrm{~kg}$ sulphur ha ${ }^{-1}$ in respect of ascorbic acid is concern. Sulphur applied @ $30 \mathrm{~kg}$ sulphur ha ${ }^{-1}$ through elemental sulphur is sufficient as compared to 45 and $60 \mathrm{~kg}$ sulphur $\mathrm{ha}^{-1}$.

\section{References}

Anonymous, 2017. National Horticulture Board, Horticultural statistics at a glance, pp.16 and 209

Channagoudra R.F., Ajjappalavara Prsbhudeva and A.S. Kamble., 2009. Response of onion (Allium cepa L.) to different levels of irrigation and sulphur in alfisoles of northern transitional tract of Karnataka. The Asian Journal of Horticulture, 4 (1):
152-155

Chesnin, L., and C. H. Yein. 1951. Turbidimetric determination of available sulphur. Proceedings of Soil Science Society of America 15: 149-157.

Qureshi A. A., and Lawande K. E., 2006. Response of onion (Allium cepa) to sulphur application for yield, quality and its storability in $\mathrm{S}$ deficient soils. Indian Journal of Agricultural Sciences. 76(9): 535-7.

Schwimmer, S., Weston, W. J., 1961. Enzymatic development of pyruvic acid in onion as measure of pungency. Journal of Agricultural and Food Chemistry 9:301-304.

Sukhatme P.V., Amble, V.N., 1995. Randomized Blocks Designs. In: Statistical Methods for Agricultural Workers, Krishi Anusandhan Bhavan, Pusa, New Delhi, India. pp: 145-156

Thangasamy A, Sankar V, Lawande K.E., 2013. Effect of sulphur nutrition on pungency and storage life of short day onion (Allium cepa L.). Indian Journal of Agricultural Science. 83(10): 1086-1089.

Tripathy, P., Sahoo, B.B., Priyadarshini, A., Das, S.K. and Dash D.K. 2013. Effect of sources and levels of sulphur on growth, yield and bulb quality in onion (Allium cepa L.). International Journal of Bioresource and Stress Management, 4 (4): 641-644.

Zeinani A.M, Zarbakhsh A, Khodadadi M., 2010. Effect of sulphur on the yield, quality and storability of two onion (Allium cepa L.) cultivars. Seed and Plant Production journal. 26(2): 153-168

\section{How to cite this article:}

Bhoite Vivek and Backiyavathy, M.R. 2019. Response of Different Sources and Levels of Sulphur on Quality and Grading of Onion (Allium cepa L.). Int.J.Curr.Microbiol.App.Sci. 8(08): 1062-1067. doi: https://doi.org/10.20546/ijcmas.2019.808.123 